\title{
Subvocal Muscle Activity during Stuttering and Fluent Speech: A Comparison
}

\author{
Asher Bar, Joyce Singer and Robert G. Feldman*
}

Electromyography has been used in the study of speech (Edfeldt, ${ }^{3}$ Hardyck ${ }^{5}$ ). Hardyck applied this technique to subvocal speech and found that only some of his subjects were aware of their subvocalization. Other studies have demonstrated that subvocal speech could appear during reading if the content, typography and grammaticality of the material are complex (Davis, ${ }^{2}$ Kryshova and Shteingart. ${ }^{7}$ Shaw, ${ }^{9}$ Sokolov ${ }^{10}$ ). Electromyography has also been used with stutterers. Williams ${ }^{14}$ reported that stuttered and non-stuttered speech differ in action potential. Stuttering and imitated stuttering involved muscular tension both different from, and in excess of normal speech. There have been no studies delling with stutterers' subvocalizations.

In this study, laryngeal muscle activity was recorded in order to investigate:

(a) whether or not the subvocalization of stutterers was measurably different from the subvocalization of non-stutterers;

(b) whether or not the laryngeal muscle activity was measurably different when a stutterer expected to stutter and when he did not expect to stutter;

(c) whether or not the laryngeal muscle activity was measurably different when a non-stutterer expected to have difficulty and when he did not expect to have difficulty.

Expectancy of stuttering, or preparatory set, has been extensively described. Van Riper ${ }^{1:-}$ explains the preparatory set as a pre-stimulus neuromuscular adjustment which selects, determines and controls the response to the expected stimulus. It is generally agreed that this motor planning or rehearsal behaviour is an important factor just before the act of stuttering. Stutterers' ability to predict the occurrence and duration of their stuttering episodes has been verified (Johnson, et al ; Van Riper and Milisen ${ }^{13}$ ). In addition, some physiological changes in the individual prior to stuttering have been reported. Changes have been noted in breathing, pulse rate, vaso-constriction and muscle

\footnotetext{
* Asher Bar, Chief, Speech and Hearing Center, Mount Sinai School of Medicine, City University of New York.

Joyce Singer, Massachusetts Eye and Ear Infirmary.

Robert G, Feldman, Chairman, Department of Neurology, Boston University.
} 
tension (Fletcher ${ }^{4}$, Robbins ${ }^{8}$, Travis, et al. ${ }^{11}$ ). It has been shown i.lready that stuttered speech exhibits a difference in the subvocal laryngeal muscle activity prior to anticipated stuttering; this also should be observable on electromyography.

\section{Method}

One clinically diagnosed severe adult stutterer and one non-stutterer were used in the study. Both subjects were university students and were matched according to sex, age and education. The same procedure was administered to both of them. Stuttering included audible prolongations and repetitions of sounds, syllables and words.

A needle electrode was inserted into the cricothyroid muscle. A model 302, Mediton electromyograph was used. Attached was a Stereo tape-recorder. The oscilloscope was built into the unit. Channel A recorded muscle activity, and the voice was recorded on Channel B. Sensitivity was set at 200 microvolts per centimetre for both channels. The tape was played back on an Ampex Stereo tape-recorder to a Model 502 Tektronics Cathode Ray Oscilloscope. Both beams were photographed at $22.5 \mathrm{~mm}$ per second on a $35 \mathrm{~mm}$ Kymograph Camera, with a Model C-4 Grass Oscilloscope. Subvocal muscle activity was observable in both subjects, in pre-experimental trials. Words were projected by a slide projector. in random order, one at a time. A total of three hundred words was available. One hundred and fifty of the words were uncommon polysyllabic words of at least three syllables, and the rest were monosyllabic, common words. Difficult words were included to make the presence of subvocalization more likely, and to elicit expectation of difficulty in the non-stutterer. The subject was able to indicate, nonverbally, whether or not he expected to have difficulty with the word. The words were presented at regular time intervals of twenty seconds. Each word was presented on a screen for ten seconds, during which time the subject was instructed to say the word to himself. This period was followed by a blank screen for another ten second interval during which time he was instructed to signal. nonverbally, whether or not he expected to have difficulty. After signalling he said the word aloud.

The examiner noted one of the following types of response:

Type 1. The subject indicated he would have difficulty and he did. Type 2. The subject indicated he would have difficulty and he did not.

Type 3. The subject indicated he would not have difficulty and he did not.

Type 4. The subject indicated he would not have difficulty and he did.

Journal of the South African Logopedic Society, Vol. 16, No. 1, Dec. 1969 


\section{Results and Discussions}

Both inter- and intra-subject comparisons were made. Since there were only two subjects, the nonparametric Wilcoxon t-test was used to determine the significance of differences. All differences discussed below were significant at the .05 and .01 levels of confidence.

The stutterer demonstrated the earliest onset of muscle activity, and the longest time period between onset of muscle activity and onset of voice in a Type 1 response (anticipation of stuttering followed by actual stuttering). The short latency period from the presentation of the signal to onset of muscle activity indicated that the stutterer began preparing to say the word much earlier when he anticipated difficulty and had difficulty, than when he anticipated difficulty and had none (Type 2 response), or when he did not anticipate difficulty and had none (Type 3 response). The results also indicate that the stutterer began to prepare earlier for a Type 2 response than for a Type 3 response. Since the non-stutterer did not have difficulty in speech and production, there were only Type 2 and Type 3 responses to compare. The non-stutterer began to prepare earlier when he expected difficulty than when he did not. Thus, both the stutterer and the non-stutterer began to prepare to speak earlier when they anticipated difficulty, although when the subjects were compared with each other, the stutterer's preparation began significantly sooner than the non-stutterer's in each instance. This early muscle activity might be one of the physiological parallels of the behaviour referred to as expectation, anticipation, or fear. In addition, this result might suggest that although both stutterers and nonstutterers exhibit muscular reactions when confronted with a difficult task of speaking, the stutterer as a result of his long and severe history of stuttering showed almost instant preparation. The normal speaker, who had no history of stuttering, exhibited slower onset of muscular adjustment.

Only the stutterer demonstrated earlier onset of muscular activity once the signal had been given to say the word aloud. The nonstutterer had more electromyographic activity or subvocal speech in the ten second period of preparation prior to the signal to say the word aloud. These findings might appear to be somewhat inconsistent. It is explained, possibly, in the following manner. In an everyday situation, there would be two types of speech: unrehearsed, where little preparation is involved, and situations where it is known that speech will be called for, such as in making a telephone call. The word flashing on the screen, signalling a time to speak, might be compared with unrehearsed speech whereas the ten seconds of preparation in this study might be compared to the second situation. It would appear then, that there are two ways of preparing for speech. 
The results of this study suggest that the stutterer initiates earlier muscle activity of preparation once the signal for speech has been given even though the non-stutterer also makes some preparation at this time. On the other hand, it appears that the non-stutterer uses the ten seconds of preparation for muscular adjustments to a much greater degree than does the stutterer. It seems reasonable to ally fluency or controlled speech with more rehearsal, and stuttering or uncontrolled speech with less rehearsal behaviour. In the case of the stutterer, it seems that the preparatory set and rehearsal behaviours discussed in the literature are confined to that period between the signal (demand) to speak and actual speech, and not to silent speech. The normal speaker seems to use that period of silent speech to establish a preparatory set. This suggests that if the stutterer would begin to prepare his speaking earlier, he might demonstrate more control of his speech.

Potential therapeutic value may be found in the application of these findings to the training of stutterers to use their preparation period more effectively. Such a procedure of training has been suggested already by Hardyck ${ }^{5}$ and Basmajian' ${ }^{1}$ who have experimented with muscle activity and electromyography. They demonstrated that when their normal subjects were allowed to view their muscle activity on the oscilloscope and listen to the muscle static through earphones, they were able to exert great control over the muscle in which the electrode was inserted. Within about one hour the subjects were able to control the muscles to fire in given rhythms or to render them in a complete state of rest. It would be interesting to note in future studies what effect such a procedure would have on a stutterer's overt speech, if he were trained to use electromyography to control his muscles in similar patterns to those found in normal speakers.

The results and suggestions made in this paper are tentative since they are based on a pilot study. However, it appears that the study of the subvocal mechanism of stutterers might explain some of the observable phenomena associated with the moments prior to, and during stuttering. Larger populations of subjects are needed before the hypotheses suggested in this study can be confirmed.

\section{Acknowledgments}

The authors acknowledge the assistance of the staff of the Department of Neurology, V.A. Hospital, Boston.

\section{Summary}

Electromyography measurements utilizing needle electrodes, were made to compare the laryngeal muscle activity of a stutterer and a 
non-stutterer, (a) when they indicated anticipation of either difficulty or no difficulty speaking, (b) when they actually spoke. The stutterer exhibited the earliest and longest laryngeal activity when he anticipated difficulty and actually stuttered. The stutterer exhibited more intense muscle activity before speaking than the non-stutterer. Therapeutically, it is suggested that stutterers learn to control the muscle activity prior to the moment of speaking.

\section{Opsomming}

Daar is gebruik gemaak van elektromiografiese metings (naaldelektrodes is gebruik) om die laringeale spieraktiwiteit van 'n hakkelaar en 'n nic-hakkelaar te vergelyk. Spieraktiwiteit is onder die volgende omstaridighede bepaal:

(a) wanneer hulle verwagting aangedui het van of moeite met- of geen moeite met spraak nie.

(b) tydens werklike spraak.

Spieraktiwiteit het vroeër begin en langer aangehou by die hakkelaar wanneer hy verwag het om te hakkel en ook terwyl hy werklik gehakkel het. Die hakkelaar het ook meer intense spieraktiwiteit voor die aanvang van spraak getoon as die nie-hakkelaar. Terapeutiese leidrade hieruit verkry is dat hakkelaars geleer moet word om die spieraktiwitcit voor die oomblik van hakkel te beheer.

\section{References}

I. Basmajian. J. V. (1963): Control and training of individual motor Inits. Science, /41, 440-441.

2. Davis, R. C. (1938): The relationship of muscle action potentials to difficulty and frustration. Journal of Experimental Psychology, 23, 141-158.

3. Edfeldt, A. W. (1960): Silent speech and silent reading. Chicago: University of Chicago press.

4. Fletcher, J. M. (1914): An experimental study of stuttering. Journal of Applied Psychology, 25, 201-249.

5. Hardyck, C. D., Petrinovitch. L. F. and Ellsworth, D. W. (1966): Feedback of speech muscle activity during silent reading: rapid extinction. Science, 154, 1467-1468.

6. Johnson, W., Knott, J. R. and Webster, M. (1937): A quantitative evaluation of expectation of stuttering in relation to the occurrence of stuttering. Journal of Speech Disorders, 2, 101-104.

7. Kryshova, N. A, and Shteingart, K. M. (1964): A study of internal speech following a disturbance of the speech motor analyser function. Doklady Akademii Navk USSR, 4, 998-1000.

8. Robbins, S. D. (1919): A plethysmographic study of shock and stammering. American Journal of Physiology. 48, 285-330.

9. Shaw, W. A. (1940): The relation of muscular action potential to imagined weight lifting. Archives of Psychology. 35, 5-50. 
10. Sokolov, A. N. (1961): Studies on the problem of the speech mechanism of thinking. Psychological Studies in the USSR., 1. 669.

11. Travis, L. E., Tuttle, W. W. and Cowan, D. W. (1936): $A$ study of the heart-rate during stuttering. Journal of Speech and Hearing Research, $1,21-26$.

12. Van Riper, C. (1937): The preparatory set in stuttering. Journal of Speech and Hearing Disorders, 2, 149-154.

13. Van Riper, C. and Milisen, R. L. (1939): A study of the predicted duration of the stutterer's blocks as related to their actual duration. Journal of Speech Disorders, 4, 339-346.

14. Williams, D. (1955): Masseter muscle action potential in stutterers and non-smiterers. Journal of Speech and Hearing Disorders, 20, 242-261.

Journal of the South African Logopedic Society, Vol. 16, No. 1, Dec. 1969 